species, found west of the Rocky Mountains, extending south to Guatemala.

A. amazili is strictly a South American species extending to the north to the Antilles and Central America.

There are two species in Australia, three in Europe, four in Africa and perhaps ten in Asia.

\title{
THE ARGYNNIDES OF NORTH AMERICA.
}

\author{
BY IIENRY JOIIN ELWES, CIRENCESTER, ENGLAND.
}

[Reprint, p. 563-575, from "A revision of the genus Argynnis," (Trans. ent. soc. London for the year $1889, p \cdot 535-575)$.

The Argynnides of North America are, without exception, the most difficult butterflies to classify that I have ever studied. I have a collection which includes authentically named specimens of almost all the species and varieties, many of them direct from such wellknown collectors as Messrs. H. Edwards and Morrison ; many from Messrs. Strecker and Geddes. I have also seen some of the best collections in the United States, and studied all, or almost all, the large mass of scattered literature and notes on the genus by Messrs. W. H. and H. Edwards, Mead, Geddes, Scudder, and Strecker. I have repeatedly tried to construct a key by which the supposed species could be identified, and can only say that I have completely failed. I am certain that no entomologist, who received to-day the most perfect collection which could be got together from all parts of North America, and had to classify and describe them without regard to the works of others, would make anything like as many species as have been recognized. It seems presumptive for a man to set aside much of what has been written by those who have seen, both living and dead, so many more specimens than I have seen, and yet I cannot, in dealing with the American forms, adopt as specific, characters so slight and variable that they would not be recognized as such in the much better known European species. And to show that it is not my ignorance alone which makes the difficulty, I may say that it is just those species which I have personally observed in life, and which I have most carefully examined, such as $A$. eurynome, $A$. liliana, A. monticola, and A. meadii, in which I have found my uncertainty the greatest. Mr. Strecker's remarks, on p. I 8 of his Catalogue, are so much to the point that I will quote them here, and can only say if our American colleagues do not agree with them, let them rather point out how others may under. 
stand their conclusions, than blame me for not adopting what I cannot see :"The Argynnides of the western slope, or Pacific side of the Rocky Mountains, are without doubt, if we except, perhaps, the Coliades, the most difficult of all the North American Diurnae to deal with, as they not only run into certain variations, but again into subvariations, or even further. The two species monticola and zerene, first considered identical by Dr. Boisduval, are perhaps the most perplexing; each of the,e bears the same relation to some of their varieties as does niobe to its var. eris and adippe to cleodoxa, but presenting by no means the stability of forms of these European variations, but branching out into endless and endless varieties until the student is completely at a loss to know where or to what they may belong."

Scudder, in the "Butterflies of New England,' has figured the abdominal organs of several species of Argynnis on plate 33 which gives an opportunity of comparing some nearly allied species. Thosc of $A$. cybele, fig. 44, $A$. aphrodite, fig. 40, are very similar indeed, but as they do not appear to agree exactly with the descriptions, and the figure of that of aphrodite is not alluded to in the description on p. 565 , I do not know whether the description was made from the same specimens figured, and whether we are to attribute the difference to variation, or to incorrect drawing. The clasper of atlantis fig. $3^{6}$, also much resembles those of cybele and aphrodite, but has the hook longer and nearer the clasp. The figure of the androconia of these three species, plate 46 , figs. I $2, I_{3}, I_{4}$, are also very similar, and, taken in connection with the claspers, do not lead one to suppose that very much help will be given in deciding the relationship of nearly allied species in this genus by a microscopic examination. The claspers of A. myrina, bellona, and montinus, plate 33 , figs. $35,38,4^{2}$, all included by Scudder in the genus Brenthis, show a general similarity of form inter se, with the same minor differences as those of cybele, aphrodite and atlantis. I at first supposed that some difference might be found in the scales clothing the median veins in the males, but on examination with a powerful lens idalia is the only North American species in which the raising is conspicuous, though in some specimens of atlantis and aphrodite, and others, it is clearly perceptible. The tuft of silky hairs on the subcostal nerve is present in the males of all the larger species that I have examined, and is very conspicuous in idalia, but I have not found it in the smaller species which have been separated under the genus Brenthis.

$A$. idalia and A. diana are two of the most beautiful species in the whole genus, and may be said to form the best links between those species of Eastern Asia, which end the Palaearctic series, and the American species, which are isolated from them. A. diana has the sexes more different than any except sagana, and if the genus was divided into groups would be another instance of an American species having its 
nearest affinities in Northeastern Asia and Japan, of which we have several among the plants of the Alleghany Mountains.

A. aphrodite, A. cybele, A. alcestis, A. cypris, A. halcyone.-This is a group of species or forms which are extremely hard to define, and though Edwards and Scudder, and most other North American entomologists, agree in keeping them separate, I think it is very difficult, if not impossible, to identify them unless you know their habitat. I have a pretty good series of all except cypris, which must be very close to, if not identical with, alcestis, and judging by the character of the median veins in the fore wing of the male, by the color and pattern of the under side, which are the best characters I know by which to define the species, I am certainly inclined to follow Strecker rather than Edwards. There have been so many mistakes made in identifying these species by collectors that their geographical distribution is not very easy to follow out; though Mr. Scudder's maps are useful, they are by no means infallible, and the northern and western range of aphrodite and cybele is certainly not defined at present. I received from Morrison a pair of cybele from Montana, which agree with those taken by Geddes in the Northwest Territory of Canada, near Edmonton, being smaller than those from the eastern states. According to Scudder and Edwards, however, cybele does not occur in Montana, and the Edmonton habitat is quite isolated; whilst aphrodite, which is unmentioned by Geddes in his lists of north-western butterflies in Canadian entomologist: vols. 15, p. 221,16, p. 56 and 224 , is stated by Scudder and Edwards to occur at Edmonton. Either such experienced collectors as Morrison and Geddes did nor know aphrodite when they saw it out of its usual range, or Scudder and Edwards are mistaken. Though it seems undoubted that typical eastern specimens of these species can be distinguished (for the points of difference see Scudder, p. 566), yet the differences are so slight that it may not be possible to identify western specimens with one or the other, and this difficulty seems to have been got over in Edwards' case by creating other species, such as alcestis, cypris, and halcyone, which cannot be identified with any certainty from his figures or descriptions; and which, notwithstanding all that has been written upon them, must remain, as far as I can see, "species dubiae" to those who have not specimens identified by their author at hand for reference.

$A$. leto is a species which, though undoubtedly nearly allied to cybele, is fully as distinct from it as nokomis, and may be regarded as its Pacific coast form, in the same way as nokomis is the form of the dry central platean of the continent. Though the male is not very different from the male of cybele yet the female, which on the upper side is hardly distinguishable fro'n the females of nokomis and notocris, is marked by the strong contrast between 
the deep chocolate, almost black, of the base and inner area of the wings and the pale yellowish color of the area. Its range extends along the Pacific coast from Central California to Washington Territory, and it is recorded also by Geddes from Fort Macleod, in the Northwestern Territory of Canada, on the eastern side of the mountains. 'Those I have from Washington Territory are considerably darker at the base of the hind wings than others from Plumas county, California; and I should not be at all surprised if a large series from different localities were to show forms intermediate both with cybele and nokomis.

A. carpenteri is unknown to me, except from the description, which seems to point to a form of cybcle. It was described from two males and one female taken by Dr. Carpenter in New Mexico at a high elevation above the timber line, and is said by Mr. Edwards to be of the size of atlantis and near cybele.

A. nokomis and nitocris are regarded by $\mathrm{Mr}$. Edwards, in his last catalogue, as distinct; he cites, however, Strecker's figure of nokomis female, in Ruffiner's report, as an aberration of nitocris. This is just one of those cases which prove how difficult it is to follow Edwards's authority in such matters. It so happens that I have two excellent pairs of nokomis from Arizona, sent by $\mathrm{Mr}$. H. Edwards, which exactly agree with Mead's figure cited by Edwards. I have also a pair of nitocris, the male from Utah, sent by Mr. Strecker, the female from Arizona, agreeing with it, so marked by Mr. H. Edwards. "I think this species passes as $A$. nitocris, female." It differs from nokomis in having the under side of hind wing to the second row of spots cinnamon-color, as in $c y$ bele, and is exactly intermediate between nokomis and leto. The specimen figured by Strecker in Ruffiner's report, and cited by Edwards as an aberration of nokomis, is, to my eye, much more like leto than it is to nitocris or nokomis; and Mr. Strecker's remarks are as follows:-6'The present two examples from Colorado differ notably from all those from Arizona in the following particulars: On under surface the red color of primaries is darker, and covers evenly the whole wing except toward and at the apex; on the secondaries the whole space interior to the second of the two outer rows of silver spots, which in the Arizona examples is powdered greyish green, is deep reddish brown, nearly of the same color as in the female aphrodite, or the male of leto; they are larger than most of those I have scen from Arizona. On the upper side it presents no differences. I have always contended that nokomis was a pale abnormal form of cybele, of which we have so many other instances in the species from the dry salt regions of Utah and Arizona, and these intermediate examples from Colorado, with their dark reddish under sides, seem to strengthen my opinion. I can but regret that no males were captured (unless the following be really its male)*, as I consider this is

*'This is put down as cybele by Mr. Strecker, who is astonished at receiving it from Colorado, and is strongly 
by far the most interesting insect in the whole collection."

A. aphrodite is a very wide-ranging species, which varies enough in the Western States to have received at least three names, for I cannot see how to distinguish alcestis or halcyone in the perfect state, though Edwards says the larva of alcestis is different, and places halycone in a different subgroup with coronis, calippe, and edwardsi, on account of the larger and more eggshaped form of the silver spots on the under side. When, however, a good series is compared together (I have sixteen males and twelve females of this group from various States), I cannot see that his supposd distinctions are constant, and though nausicaa, of which I have four males and five females, taken by Messrs. Hulst and Morrison, is distinctly of a deeper red on the upper surface than any of the rest, yet its under side, like that of halcyone, has nothing sufficiently marked to distinguish it. $\mathrm{Mr}$. Edwards perhaps would say that my halcyone, which were sent by $\mathrm{Mr}$. Strecker, and taken near Denver, are not true to name; but what else can they be from that locality? It only shows that if a describer of insects does not make his descriptions sufficiently comparative and clear to be followed by others, he must not be surprised if others refuse to accept them. Larval characters alone, which are liable to vary like those of the perfect insect, and which cannot be easily compared by

inclined to the belief that it is the male of the above described form of nokomis. others, are not in my opinion sufficient.

With regard to $A$. nausicaa, however, I see a point not alluded to by $\mathrm{Mr}$. Edwards, which may be sufficient to separate it, namely, the much less abundant and shorter tuft of hairs on the subcostal vein of the hind wing in the males. This tuft is prominent in all males of aphrodite, alcestis and halcyone which I have examined; in nausicaa it is much less conspicuous, and, taken in conjunction with the isolated habitat and deeper color, is probably enough to distinguish it.

A. ailantis is another species which I find it uncommonly difficult to decide about, not so much when the eastern form alone is before me, but when the numerous western species or forms have to be considered. Mr. Edwards has got over the difficulty by naming them all separately, and Mr. Scudder, though he was not perhaps obliged to mention them in the 'Butterflies of New England,' says nothing as to their very near relationship. He remarks as follows:- "'There is no need of confounding this species with either of the preceding [aphrodite and cybele ]: it is smaller than they, duller in tint above, has a blackish border to all the wings in both sexes, and more continuous mesial band on the upper surface of the hind wings; the darker colors of the under surface of hind wings are deeper in hue than in either of them, while the buff belt is wider than that of aphrodite and narrower than that of cybele; the buff scales on the basal half of the wing also assume more im- 
portance thin in the other species; finally the costal border of the fore wings does not appear to be quite so much arched. It is possible, perhaps even probable, that this species is the true Papilio aphrodite of Fabricius, but as it is quite impossible to be certain of it, the names ought to stand as given by Mr. W. H. Edwards, who first clearly distinguished the species in this difficult group. The species were still confounded in the British Muscum, after the publication of Butler's Fabrician butterflies, as I myself saw, and notwithstanding Butler's remarks on p. IoS of that work." Its distribution, according to $\mathrm{Mr}$. Scudder, is much the same as that of cybele and aphrodite, but extends to Newfoundland, Labrador, and the Hudson Bay Territory; on Mead's authority he also gives Colorado, but Edwards calls the form found here electa, which also ranges into New Mexico and Montana. Whether this is the same or not I cannot be certain, as the description of electa in 'Field and Forest' is inaccessible; but I have a pair from Colorado, given me by Mr. Holland (which are named electa, I believe, by Mr. Edwards), and a female from S. W. Colorado, taken by Morrison, which I cannot separate from atlantis. Mead also gives a clue to the correctness of this identification with atlantis by mentioning the strong musky odor of the Colorado species, a peculiarity of atlantis to which Scudder calls attention. Geddes says that atlantis occurs in all parts of the Rocky Mountains north of the
American boundary which he visited, and if this is correct, it can hardly be absent from Montana and Colorado. But at the same time I must say that the male of so-called electa does not differ from the female as does another male from Colorado (sent by Mr. H. Edwards as hesperis) in having the silver spots of the under side partially obsolete. If, therefore, hesperis and atlantis, which are placed next to each other by Mead, and stated to occur at the same elevation in Colorado, run into each other, as they seem to do, we are led into the belief that atlantis is liable, in the west, to the disappearance of the silver spots, which takes place in other American and European species; and then there is no reason why some of the forms which occur on the Pacific States, such as columbia should not also belong to atlantis. I do not say that they are so because it would be unwise to do so without knowing them in nature better than $I$ or any living American naturalist does; but on the other hand I can see nothing in the writings and figures of $\mathrm{Mr}$. Edwards to prove the contrary, or to enable others to distinguish them. A. columbia H. Edw., was by him considered as so near to atlantis that it might be only a variety of it. It was described from four males taken at Lahache, near the Alaskan border of British Columbia, and there is nothing in the description worthy of note; but, when going through $\mathrm{Mr}$. Edwards's collection, I noted it as similar to hesperis. 
A. lais, of which I have seven of the specimens from Red-deer River, from which the species was described, seems to me very near atlantis, but separable by the smaller size, paler color, and apparently by the less raised scales of the submedian veins in the male. Edwards, however, says it is of the size of atlantis, and stands between that and aphrodite. Geddes does not tell us how to distinguish them, but says that it was found on the prairies about Fort Edmonton, while atlantis occurred in the mountains.

A. coronis is a species which seems to have a very wide range west of the Rocky Mountains, and varies a good deal, but may be recognized in most of its forms by the large ovoid silver spots of the under side of the hind wing. It is apparently most nearly allied to edwardsi, with its forms nevadensis and meadii, but these differ in the longer, narrower shape of the fore wing, and do not seem to be fornd on the Pacific coast. There occur, however, in Nevada forms which are described as laura and macaria, of which I have authentic specimens from Mr. II. Edwards, and which, by their under sides, seem to be coronis; whilst chitone, also sent by Mr. H. Edwards from Nevada, docs not agree with W. H. Edwards's description on the under side, and is nearer to nevadensis.

None of these names can, in my opinion, be retained except as synonyms, though they are all three kept up in Mr. W. H. Edwards's I 889 Catalogue as distinct species.
Whether edwardsi, nevadensis, and meadii are distinct is a more doubtful question. Certainly meadii, which I have taken in the Yellowstone Park, looks very different from the large edwardsi of Colorado, but I have some from Montana, taken by Morrison, and from the N. W. Territory of Canada by Geddes, named nevadensis, which are perfectly intermediate in size and color; whilst others, sent by Strecker as nevadensis from Colorado, resemble aphrodite in the color of their hind wings below. Mead says:-_"The three closely allied species, edwardsi, nevadensis, and meadii seem to be related to each other in much the same way as the eastern aphrodite, cybele, and atlantis. In edwardsi the pale submarginal band below is narrower, and sometimes almost obsolete, as in aphrodite, and it ranges up to greater elevations than nevadensis, which has this band comparatively broad in both sexes, as we see it in cybele. Meadii differs from either in tint, especially the female; it is somewhat smaller, and probably, like atlan$t i s$, is exclusively confined to the mountains. The peculiar bright green coloration of the under side of secondaries $i_{n}$ meadii, however, has no parallel among our fritillaries."

A. callippe is, in its typical form, which occurs'all through the lowlands of California, a very distinct species; but liliana is, according to Mr. H. Edwards, intermediate between it and coronis, and the specimen which he sent me as typical of it does not agree with those which Mr. Grodman and I took 
abundantly near Los Angeles, some of which Mr. H. Edwards afterwards named liliana, though I should certainly call them callippe.

A. scmiramis, again, is a South Californian form, which has been taken by Mr. Wright in the mountains separating the San Bernadino Valley from the Mohave Desert, and of which I have six specimens from him, as it was not yet out when I visited these mountains in May, 1888 . To my cye it is nothing more than a form of coronis, in which the black markings on the upper side have become paler and more reduced, as might be expected from the arid character of the country where it is found. Edwards says :- "It is curious how the markings resemble two such distinct species as adiante (upper side) and coronis (lower side)."

The species allied to monticola, namely zerene and bremneri, have puzzled me quite as much as Edwards, Strecker, and others, and I do not see how the difficulties of their synonymy can ever be cleared up; but I can only say that, if I have not succeeded in arranging them correctly, it is not from idleness or carelessness, but on account of the impossibility of identifying species or forms described in such a way as these have been. Many of the names cannot be certainly identified, and had better be dropped. I think, however, that three more or less distinct forms can be recognized among the very numerous specimens which I have from the Pacific States. These are a larger form monticola, and a smaller form, which both
Messrs. H. and W. H. Edwards call zerene, $\mathrm{Bdv}$. These both vary extremely on the under side, but in monticola, the males occasionally, and the females usually, have more or less silvery spots ; whilst in zerene the duller and paler color of the under side is without any silver except on the marginal row. These distinctions, however, are based upon Californian specimens, mostly from the Shasta district, and, according to Edwards's opinion in I879 (see Can. Ent. p. 55-56), do not apply to Nevada specimens. He then considered monticola to be only a var. of zerene, but put them down as two species in his catalogue of 1884 . Further north, in the damper climate of Oregon and Washington Territory, as also commonly in Vancouver's Island, a darker form, bremneri, occurs, which on the under side is well spotted with silver in both sexes, and might be considered as the Pacific coast form of atlantis, but in the specimens taken on Mount Hood by Morrison (rhodope Edw.), and also occasionally in Vancouver, the silver is absent, and these specimens might well be considered as a northern and darker form of zerene.

A. hippolyta, which is also kept up by its author as a species, is described without reference to its allics, and seems to be something intermediate between hesperis and some form of zerene or monticola. Its locality would indicate that it may be nearer to them than to atlantis. It was described from four males and one female only.*

\footnotetext{
*Mr. Strecker informs me that hippolyta was de.
} 
A. adiante is a form which both Strecker and Edwards consider distinct, and which appears to be very local. On the coast of California, according to Strecker's information, it is now extinct, and all the male specimens (I have seen no females) in Mr. Godman's and my collection were evidently taken many years ago. But, though the markings on the under side are nearly obsolete in some cases, and in all faint compared with those of zerene or monticola, yet they seem to be quite identical, and I should certainly be inclined to set it down as a variety of one of those species. This is just a case in which one would be guided by the opinion of local collectors, but neither Mr. H. Edwards or any one else of late years seems to have mentioned this species, and the opinions held twenty-five years ago, when Dr. Behr was an active collector, are not conclusive.

The intricacy and confusion of nomenclature among the next group of Argynnides, which inhabit the Rocky Mountains and Pacific States, is as great as among the last, but $I$ have in this case followed Edwards's identifications of Behr's and Boisduval's species, which are supported by the named specimens sent me by Mr. H. Edwards, rather than the arrangement of Strecker's Catalogue, which makes montivaga and egleis varieties of zerene, Bdv. I cannot, however, follow Edwards in separating

scribcd from some small examples of bremneri, given by Mr. O. B. Johnson of Oregon, to Mr. Dodge, of Nebraska, who gave them to Mr. W. H. Edwards. Some of the same catch and lot were also given to Mr. Strecker. clio and artonis from eurynome, and Geddes, who took them in the Northern Rocky Mouutains, agrees with me in considering them as synonyms. As to opis and bischoffi, I am more doubtful, having seen but few specimens; but in these, as well as in Edwards's figures I can see no specific characters, and should consider them as northern varieties, differing only, as might be expected, in rather smaller size and duller coloration. Whether montrvaga and its var. egleis are really distinct from eurynome and its varieties is hard to say; they seem to have the fore wings rather longer and the underside less tinged with green : they may, perhaps, best be treated as the west coast representative of eurynome. Edwards says of egleis (Can. ent. v. 2, p. 54) that whatever the variation in other respects (and he allows it to be very variable), the spots of the second and third rows on the under side of hind wings are heavily edged with black on the basal side. But I have specimens of montivaga, collected by Morrison in Nevada (of which sixty were also examined by Edwards), and others from the Sierra Nevada, California, named montivaga by $\mathrm{H}$. Edwards and Strecker, which have the same character, and in some specimens of eurynome taken by myself in Yellowstone Park, the same black edging is more or less perfect.

I have also specimens of arge, Streck. from Strecker and Mr. Holland, both from Spokane Falls and California which are undoubtedly the same as erinna, which was described in 1883 as a var. of eurynome by Edwards, and in his Cata- 
logue of $\mathrm{rSS}_{4}$ is put down as a variety of montivaga. If, therefore, he is himself so uncertain of the true position of these forms, he cannot expect others to follow him blindly, and though many years must elapse before any certain conclusion will be come to, I venture to think that the arrangement I have adopted represents the facts shown by my collection, including about fifty specimens from all the States where the species occurs and from many of the collections which supplied his own materials. If it should eventually prove that the Pa- cific coast form is not separable from the Rocky Mountain form montivaga, it may be better to use the name eurynome in preference to montivaga or egleis, because both Behr's and Boisduval's descriptions which have priority over Edwards's, can only be identified with doubt. My specimens of montivaga and egleis, all come from the Sierra Nevada, and not from the Mt. Shasta district, where monticola and its vars. are so abundant; but local information as to their distribution, in this, as in the other cases, is very deficient.
Insects of Bermuna. - The Bermuda Islands by Professor Angelo Heilprin contains chapters on the insects, arachnida and myriopods of the Bermudas by Drs. P. R. Uhler, George Marx and the late Mr. C. H. Bollman. Dr. Uhler considers the species already found as almost entirely Nearctic in character but anticipates the discovery of multitudes of Neotropical forms. He does not enumerate the hymenoptera, lepidoptera, and coleoptera and his lists of the hemiptera, homoptera, pseudoneuroptera, dermaptera and diptera include but fifteen species or less than half the number recorded in $\mathrm{Mr}$. J. Matthew Jones's "Visitors Guide to Bermuda." Dr. Marx mentions seventeen species of spiders, describing Lycosa atlantica as new. Mr. Bollman notes Fulus moreleti, Spiro. bolus heilprini n. sp., Mecistocephalus guild$i_{\text {ngii, Scolopendra subspinipes and Lithobius }}$ lapidicola as all the myriopods that have been reported from the Bermuda Islands.

Description of the larva of MegaloDACNE Fasciata, Fabr.-- Color. Body sordid white, with the patches on the segments above piceous; head light brown, mandibles piceous.
Head subylobose, small, smooth, shining.

Cypleus transverse, about five times as broad as long.

LABRUM somewhat narrower than the clypeus and about twice as long, anterior margin straight with a series of strong hairs; angles rounded; sides slightly oblique.

Mandibles short and thick with the apex strongly bifid.

Antennae very short; two jointed; first joint short, and about three times as broad as long; second joint more slender and about twice as long as broad with the apex somewhat rounded.

Maxillat elongate, rounded at the apex with hairs and a few bristle-like short tubercles.

MAXILLARY PALPI three jointed; first joint much broader than long; second joint, less wide; third joint more slender and longer.

Labium subcordate, apex rounded; base much broader.

Labial palpi two jointed; first joint, short, thick, twice as broad as long; second joint more slender, broader at the base than apex and about twice as long as broad.

Bopy elongate, segments all about equal width and length except the first which is 

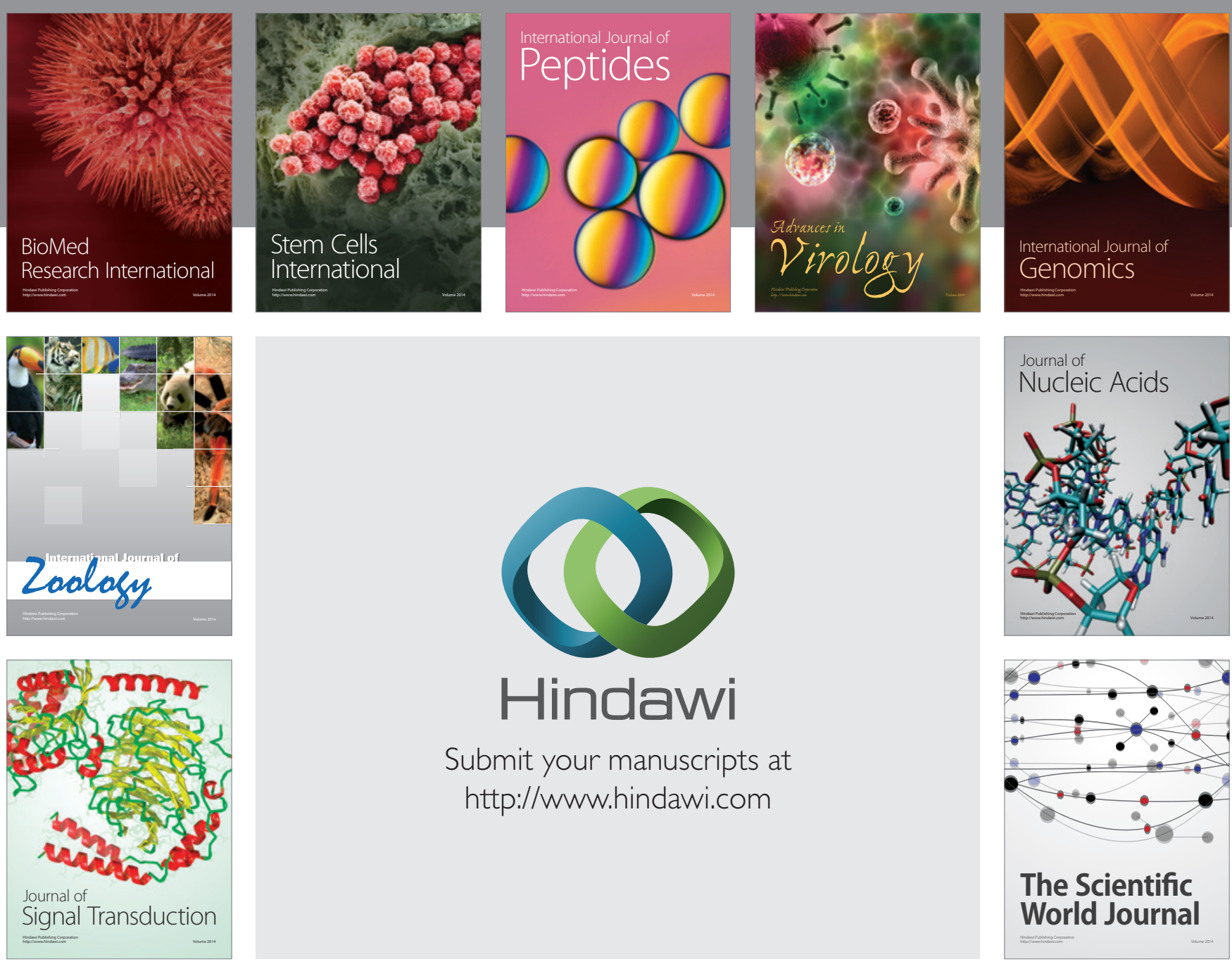

Submit your manuscripts at

http://www.hindawi.com
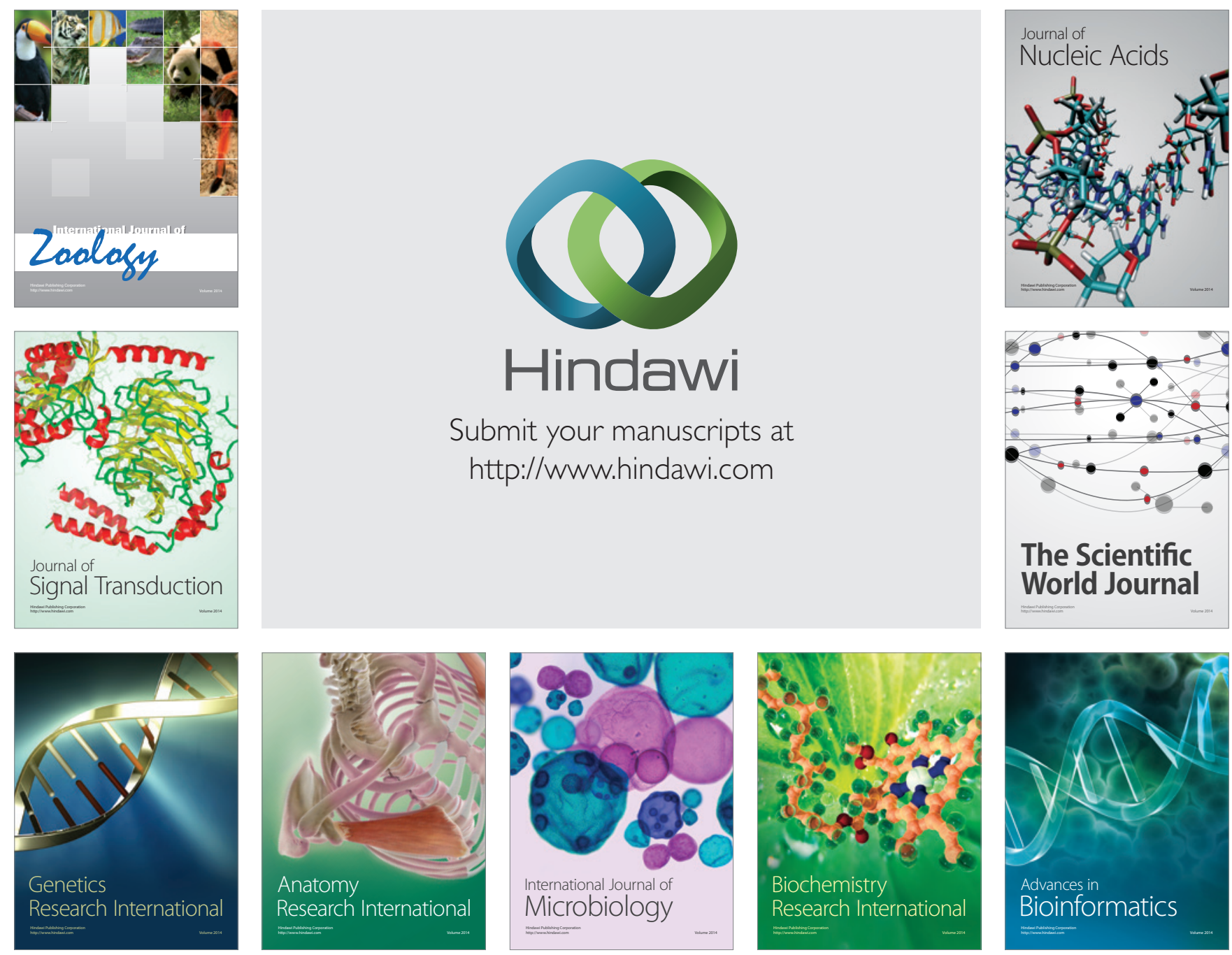

The Scientific World Journal
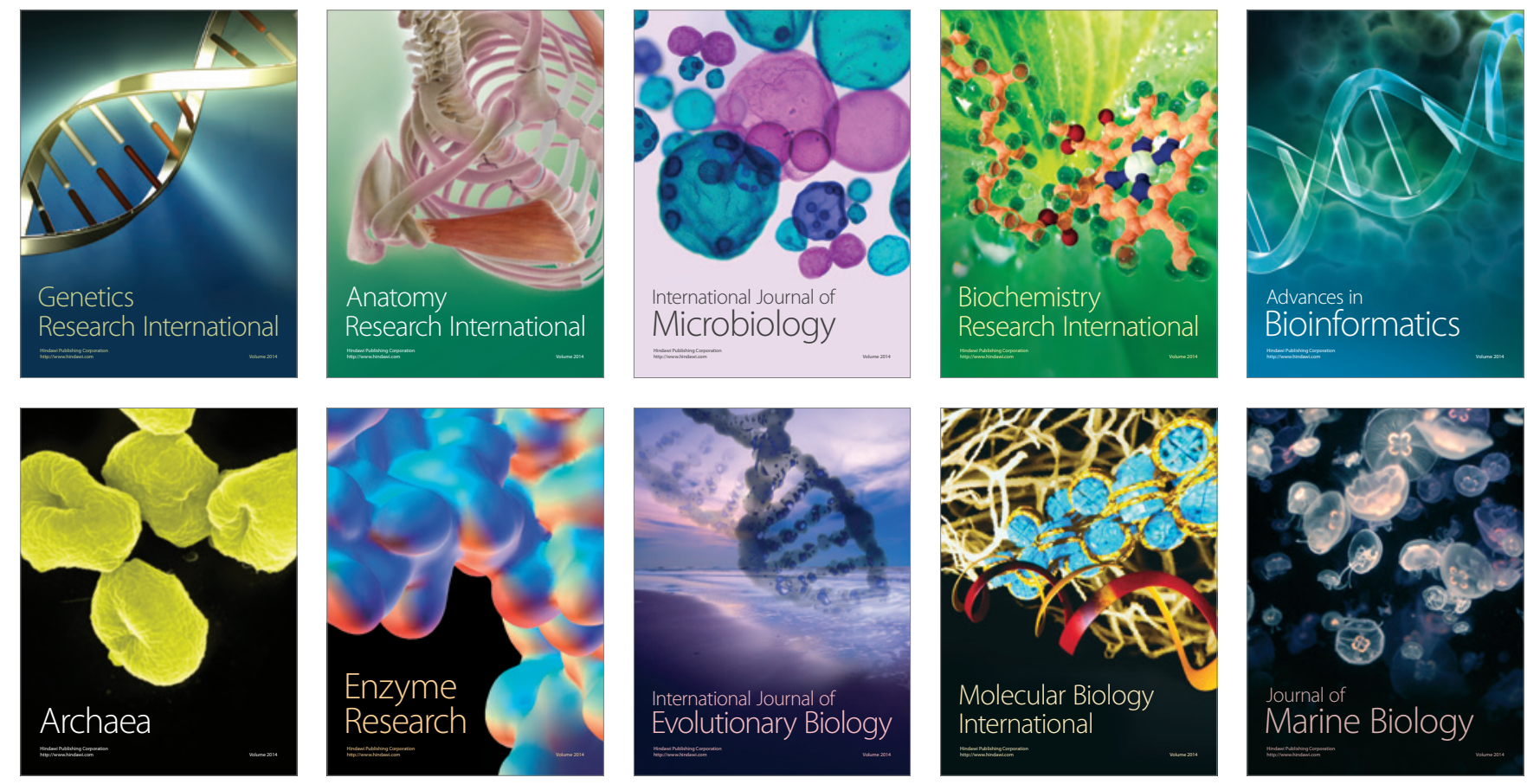